\title{
Associations Between Early Marriage and Young Women's Marital and Reproductive Health Outcomes: Evidence from India
}

\author{
By K.G.Santhya, \\ Usha Ram, Rajib \\ Acharya, Shireen J. \\ Jejeebhoy, Faujdar \\ Ram and Abhishek \\ Singh
}

K.G. Santhya is associate, Rajib Acharya is senior programme officer and Shireen J. Jejeebhoy is senior associate-all at the Population Council, New Delhi. Usha Ram is associate professor, Faujdar Ram is director and senior professor and Abhishek Singh is assistant professor-all at the International Institute for Population Sciences, Mumbai.

CONTEXT: Little evidence from India is available regarding the ways in which early marriage may compromise young women's lives and their reproductive health and choices.

METHODS: Data from 8,314 married women aged 20-24 living in five Indian states, obtained from a subnationally representative study of transitions experienced by youth, were used to compare marital, reproductive and other outcomes between young women who had married before age 18 and those who had married later. Logistic regression analyses were conducted to identify associations between timing of marriage and the outcomes of interest.

RESULTS: Young women who had married at age 18 or older were more likely than those who had married before age 18 to have been involved in planning their marriage (odds ratio, 1.4), to reject wife beating (1.2), to have used contraceptives to delay their first pregnancy (1.4) and to have had their first birth in a health facility (1.4). They were less likely than women who had married early to have experienced physical violence (0.6) or sexual violence (0.7) in their marriage or to have had a miscarriage or stillbirth (0.6).

CONCLUSIONS: Findings underscore the need to build support among youth and their families for delaying marriage, to enforce existing laws on the minimum age at marriage and to encourage school, health and other authorities to support young women in negotiating with their parents to delay marriage.

International Perspectives on Sexual and Reproductive Health, 2010, 36(3):132-139

The policy and program discourse related to early marriage (i.e., marriage before age 18 ) has increased significantly in India during the past decade. For example, several national policies-including the National Population Policy 2000, ${ }^{1}$ the National Youth Policy 2003, ${ }^{2}$ the National Policy for the Empowerment of Women ${ }^{3}$ and, most recently, the Prohibition of Child Marriage Act $2006^{4}$-have advocated special programmatic attention to helping young women delay marriage and to enforcing existing laws against child marriage. In addition, several initiatives have been launched to prevent early marriage. ${ }^{5} \mathrm{De}$ spite these efforts, substantial proportions of young women continue to marry during adolescence. As recently as 2005-2006, almost half (47\%) of a nationally representative sample of women aged 20-24 reported having married before age $18 .{ }^{6}$ The proportion is between $50 \%$ and $70 \%$ in several states.

A number of social, economic and health outcomes are associated with early marriage. ${ }^{7-10}$ For example, early marriage tends to curtail young women's educational opportunities, and those who marry early tend to have low levels of educational attainment. ${ }^{11-13}$ Likewise, studies in diverse settings have found that females who marry at young ages may be less capable than those who marry later of asserting themselves in their marriage, which may place them at higher risk of experiencing physical and sexual violence. ${ }^{14-19}$ Moreover, early marriage typically coincides with early childbearing-and young, first-time moth- ers face an increased risk of maternal and infant mortality. ${ }^{20-23}$ In addition, emerging evidence suggests that early marriage may place young women at heightened risk for STIs, including HIV. ${ }^{24-26}$

While the situation of young married women in India has been increasingly documented, 6,27-33 evidence on the ways in which early marriage may limit young women's lives and compromise their reproductive health and choices is limited. Specifically, little is known about whether marriage practices, including young women's involvement in spouse selection, differ between women who marry early and those who marry late. Similarly, little is known concerning the possible links between age at marriage and power in marital relationships, spousal communication and interaction, self-efficacy and gender-role attitudes. Finally, evidence on the extent to which sexual and reproductive practices vary by age at marriage is also somewhat limited, although not to the same extent as for the outcomes highlighted above.

To address these gaps in evidence, we used data from a large-scale survey of young people in five Indian states to compare the marital, reproductive and other characteristics and experiences of young women who had married before age 18 with those of young women who had married at age 18 or older. The survey was conducted as part of a subnationally representative study undertaken to examine key transitions experienced by young people in India. 


\section{Study Setting}

The survey was conducted in rural and urban areas of Andhra Pradesh, Bihar, Jharkhand, Maharashtra, Rajasthan and Tamil Nadu. Thirty-nine percent of the country's youth (i.e., those aged 15-24) reside in these states. ${ }^{34}$ The youth population in these states, taken together, resembles the national youth population in age, level of literacy, religion, caste and marital status.

Child marriages are extremely common in five of these states: Andhra Pradesh, Bihar, Jharkhand, Maharashtra and Rajasthan. Indeed, between two-fifths and two-thirds of young women aged 20-24 were married before age 18 in these states, compared with only one-fifth of those in the sixth state, Tamil Nadu. ${ }^{6}$ Our analyses, therefore, focus on the five states characterized by widespread early marriage.

Despite the similarity in their levels of child marriage, these five states differ in many respects. Andhra Pradesh and Maharashtra are among the more economically progressive states in the country, accounting for $7 \%$ and $13 \%$ of the national gross domestic product, respectively, while Bihar, Jharkhand and Rajasthan are among the less developed states, accounting for 2-4\% each. ${ }^{35}$ Maharashtra is one of India's most urbanized states-more than two-fifths of its population lives in urban areas-whereas Bihar, Jharkhand and Rajasthan have large rural populations, and just one-tenth to one-fifth of their populations reside in urban areas. ${ }^{36}$

Indicators of socioeconomic status and health also vary considerably among the five states. For example, in 2001, the proportion of residents aged seven or older who were literate ranged from 77\% in Maharashtra and 61\% in Rajasthan and Andhra Pradesh to just 54\% in Jharkhand and $48 \%$ in Bihar. ${ }^{36}$ In 2001-2005, life expectancy for females was higher than the national average in Maharashtra and Andhra Pradesh, but lower than average in Bihar, Jharkhand and Rajasthan. ${ }^{37}$ During 2005-2006, infant mortality rates varied from 37.5 per 1,000 live births in Maharashtra to 69 per 1,000 in Jharkhand, and the total fertility rate was at or below replacement level in Andhra Pradesh and Maharashtra but well above replacement level in the remaining three states. ${ }^{6}$

\section{METHODOLOGY \\ Study Design}

The study comprised three phases: an initial qualitative phase, a subsequent survey and, finally, in-depth interviews with selected survey respondents. The data presented in this paper are drawn from the survey.

The survey focused on married and unmarried women aged 15-24, unmarried men aged 15-24 and married men aged 15-29 (the age range was extended for the latter because of the paucity of married men younger than 20). Rural and urban areas were treated as independent sampling domains, and a multistage, stratified sampling design was adopted to select primary sampling units independently for each. In each primary sampling unit, interviews were conducted with either males or females, but not both, to avoid the risks of teasing, harassment, harm to young women's reputations and even violence associated with interviewing members of both genders from the same primary sampling unit. Households were selected by systematic sampling. If the household contained only one resident who met the age and gender criteria for participation, that person was invited to take part in the survey; if multiple residents were eligible, one person of each marital status was randomly selected and invited to participate. Selected individuals who were unavailable for interview or declined to participate were not replaced.

Fieldwork was undertaken in 2006 in Jharkhand and Maharashtra and 2007-2008 in Andhra Pradesh, Bihar and Rajasthan. About 138,000 households were enumerated, and 42,852 young people were interviewed (6,730 married men, 9,856 unmarried men, 11,905 married women and 14,361 unmarried women). Response rates were $85-90 \%$. The main reason for nonresponse was that the selected individual was not at home; rates of refusal to participate were $1 \%$ or less.

Four individual questionnaires were developed, one each for married young women, unmarried young women, married young men and unmarried young men. Questionnaire development was informed by other survey instruments and by insights obtained during the study's presurvey qualitative phase, and the resulting instrument underwent extensive pretesting. The final questionnaire included questions on background characteristics, parental interaction, gender-role attitudes, self-efficacy, awareness of sexual and reproductive matters, connectedness and friendship, experiences with and views on premarital sex, marriage planning, married life, physical and sexual violence, health, substance use, media exposure and participation in youth programs.

Data presented in this paper are drawn from a subsample of 8,314 married young women aged 20-24 at the time of the interview.

\section{Variables}

- Independent variable. We defined early marriages as those occurring prior to age 18, and late marriages as those occurring at age 18 or older.

- Background characteristics. Our analyses controlled for a number of background variables, including years of schooling completed, whether the respondent had worked before marriage, whether she had worked in the 12 months preceding the interview, her place of residence (rural or urban) and spousal age difference. Household wealth was measured using an index based on ownership of selected durable goods (e.g., means of transportation) and amenities (e.g., toilet facilities, cooking fuel); possible scores ranged from 0 to $54 .{ }^{38}$ To account for socioeconomic and cultural differences among the states, we included a variable indicating the respondent's state of residence.

We included two measures related to nonfamilial interactions. Peer connectedness before marriage was a dichotomous variable indicating whether the respondent 
TABLE 1. Selected characteristics of married women aged 20-24, by timing of marriage

\begin{tabular}{lll} 
Characteristic & $\begin{array}{l}\text { Married early } \\
(\mathrm{N}=5,277)\end{array}$ & $\begin{array}{l}\text { Married late } \\
(\mathrm{N}=3,037)\end{array}$ \\
\hline Mean age (yrs.) & 22.0 & 22.0 \\
Median yrs. of schooling completed & $\mathrm{na}$ & 9.0 \\
Worked before marriage & 31.0 & $27.0^{* * *}$ \\
Worked in past 12 months & 52.2 & $29.9^{* * *}$ \\
Resides in rural area & 84.5 & $62.5^{* * *}$ \\
Lives in nuclear family & 42.9 & $25.5^{* * *}$ \\
Participates in civic/social activities & 21.2 & 20.9 \\
Confided in peers on personal & & \\
$\quad$ matters before marriage & 36.0 & $53.0^{* * *}$ \\
Mean household wealth index score & 13.6 & $20.0^{* * *}$ \\
Mean spousal age difference (yrs.) & 9.4 & $6.5^{* * *}$ \\
\hline
\end{tabular}

*** $\leq \leq$.001. Notes: All values are percentages unless otherwise indicated.na=not applicable (because more than $50 \%$ of respondents had no formal education).

had confided in a peer regarding at least one of the following topics: taking a job, problems with friends, worries about menstrual problems and male-female relationships. Civic and social participation was a dichotomous variable indicating whether the respondent had participated in community-led activities in the past 12 months or reported membership in any organized group.

- Outcome indicators. We included a number of measures related to marriage and reproductive health as outcome indicators. To measure young women's involvement in mar-

\begin{tabular}{|c|c|c|}
\hline Measure & $\begin{array}{l}\text { Married } \\
\text { early }\end{array}$ & $\begin{array}{l}\text { Married } \\
\text { late }\end{array}$ \\
\hline \multicolumn{3}{|l|}{ MARRIAGE PLANNING } \\
\hline $\begin{array}{l}\text { Parents sought woman's opinion } \\
\text { about when to marry }\end{array}$ & 10.4 & $27.3^{* * *}$ \\
\hline \multicolumn{3}{|l|}{ Parents sought woman's approval } \\
\hline \multicolumn{3}{|l|}{ Woman had chance to meet/talk to } \\
\hline Had love marriage & 3.1 & $6.3^{* * *}$ \\
\hline Involved in marriage planning† & 4.5 & $13.9^{* * *}$ \\
\hline \multicolumn{3}{|l|}{ MARITAL RELATIONSHIP } \\
\hline \multicolumn{3}{|l|}{ Spousal communication on general matters } \\
\hline Usually discusses how to spend money & 89.9 & 88.8 \\
\hline Usually discusses in-law issues & 77.1 & $81.4^{* * *}$ \\
\hline Usually discusses both topics & 73.6 & $78.0^{* *}$ \\
\hline \multicolumn{3}{|c|}{ Spousal communication on reproductive matters } \\
\hline Ever discussed when/whether to have children & 84.2 & $87.1^{*}$ \\
\hline Ever discussed number of children to have & 86.2 & $88.7^{*}$ \\
\hline Ever discussed contraceptive use & 56.6 & 59.3 \\
\hline Ever discussed all three topics & 52.8 & $56.6^{*}$ \\
\hline \multicolumn{3}{|l|}{ Spousal interactions in past six months } \\
\hline Went to see movie & 17.3 & $31.2^{* * *}$ \\
\hline Visited other place of entertainment & 27.9 & $42.3^{* * *}$ \\
\hline Visited woman's natal home & 67.5 & $76.8^{* * *}$ \\
\hline Visited all three & 10.2 & $21.2^{* * *}$ \\
\hline \multicolumn{3}{|l|}{ Spousal violence } \\
\hline Ever experienced physical violence & 31.6 & $16.9^{* * *}$ \\
\hline Ever experienced sexual violence & 36.5 & $22.1^{* * *}$ \\
\hline
\end{tabular}

riage planning, we examined whether the respondent's parents had sought her opinion about when to marry and whom to marry, and whether she had had a chance to meet or speak with her spouse alone prior to the marriage. Respondents who answered yes to all three items, or who had had a love marriage, were classified as having been involved in marriage planning.

We examined four broad aspects of the respondent's marital relationship. The measure of spousal communication on general matters examined whether the young woman usually discussed with her husband issues concerning her inlaws and how to spend money. Spousal communication on reproductive matters was assessed by questions that asked whether the respondent had ever discussed with her husband whether and when to have children, the number of children to have and contraceptive use. To assess spousal interactions, we asked whether the respondent and her husband had gone out in the past six months to see a film, visit another place of entertainment or visit her natal home. Finally, we included measures of whether the woman had ever experienced physical violence (i.e., whether her husband had ever slapped, punched, kicked, dragged, choked, pushed, shaken or beaten her; twisted her arm; pulled her hair; thrown something at her; intentionally burned her; or threatened or attacked her with a knife or gun) or sexual violence (i.e., whether her husband had ever forced her to engage in sex) in her marriage.

We examined three areas of women's agency and gender-role attitudes. To measure participation in decision making, we asked whether the woman was involved in making decisions about choosing friends, purchasing clothes and spending money. Two aspects of self-efficacy were assessed: the woman's confidence about expressing her opinions to elders and her ability to confront a person who had said or done something wrong to her. The respondent's gender-role attitudes were examined using a question about wife-beating: whether she felt the practice is justified if a wife goes out without telling her husband, if she disagrees with her husband's opinion, if she refuses to have sex or if her husband suspects that she has been unfaithful.

Finally, we considered three reproductive health measures: whether the respondent had used contraceptives to delay her first pregnancy, whether her first birth had taken place in a health care facility and whether she had ever had a miscarriage or stillbirth.

\section{Analysis}

We compared the prevalence of each outcome among young women who had married early and those who had married later. Separate multivariate logistic regression analyses were conducted to ascertain the relationship between age at marriage and each of the indicators, after adjustment for differences in the background characteristics of those married early and late. The specific set of background variables for which we controlled varied according to the indicator under examination. 


\section{RESULTS}

Nearly two-thirds (63\%) of women in our sample had married before age 18 , the minimum legal age at marriage for females in India. Those who had married early were less educated than those who had married late: While more than half of the former had never attended school, those who had married late had completed a median of nine years of schooling (Table 1). Respondents who had married early were somewhat more likely than other women to have worked before marriage, and considerably more likely to have worked in the year preceding the interview, to reside in a rural area and to live in a nuclear family. They were less likely than other women, however, to have confided in peers on personal matters before marriage, and their households were less wealthy, on average, than those of other women. The mean age difference between women and their spouses was greater for those who had married early than for those who had married late.

\section{Marriage Planning and Marital Relationship}

Compared with young women who had married at age 18 or older, those who had married early were less likely to have been consulted on the timing of marriage and choice of spouse, as well as to have had an opportunity to get to know their spouse before marriage (Table 2). For example, the proportion of young women who reported that their parents had asked them about their preferred age for marriage was substantially smaller among those who had married early than among those who had married late (10\% vs. $27 \%$ ). Likewise, while nearly two-thirds (63\%) of young women who had married late reported that their parents had sought their approval of the spouse chosen for them, only about one-third of those who had married early had been consulted. Opportunities for meeting or talking with their husband-to-be before marriage were limited for all young women, but especially for those had married early-only $8 \%$ had had such a chance, compared with $20 \%$ of those who had married later. Similarly, those who had married before age 18 were less likely than other women to report having a love marriage ( $3 \%$ vs. $6 \%$ ). In total, only $5 \%$ of young women who had married early and $14 \%$ of those who had married late reported having been involved in planning their marriage-defined as having been consulted about when and whom to marry, and having had the chance to interact with their spouse-to-be prior to marriage, or as having had a love marriage.

Age at marriage was associated with most of our measures of the marital relationship. For example, young women who had married early were less likely than those who had married late to report regularly discussing with their husband both issues related to their in-laws and those related to spending money (74\% vs. 78\%). A similar difference (53\% vs. $57 \%$ ) was apparent in the proportion who had communicated with their husband on all three reproductive topics probed in the survey-when or whether to have children, how many children to have and contraceptive use. Moreover, young women who had married before age 18 were considerably less likely than those who had married later to report having interactions with their husband; for example, just 17\% of those who had married early reported that they had gone out with their husband to see a film in the past six months, compared with $31 \%$ of those who had married late. Similar differences were evident with regard to visiting other places of entertainment and the young women's natal home. In total, 10\% of respondents who had married early and $21 \%$ of those who had married late reported that they had visited all three locations with their husband in the past six months.

Experience of spousal violence also differed by women's age at marriage: Thirty-two percent of those who had married early reported having ever experienced physical violence perpetrated by their husband, compared with $17 \%$ of those who had married late. Findings were similar for experiences of sexual violence (37\% vs. $22 \%$ ).

\section{Agency and Gender-Role Attitudes}

Early marriage was associated with reduced levels of autonomous decision making and self-efficacy. For example, $73 \%$ of young women who had married early were involved in decisions related to purchasing clothes for themselves, compared with $78 \%$ of those who had married late (Table 3). Similarly, the proportion of women who were involved in all three decision-making domains was lower among those who had married early than among those who had not (67\% vs. $72 \%$ ). Moreover, women in the early marriage group were less likely than other women to report confidence in expressing their opinions to elders ( $25 \%$ vs. $33 \%$ ), confronting a person who had said or done something wrong to them (31\% vs. $35 \%$ ) or both ( $16 \%$ vs. $23 \%$ ). More than half of young women expressed

\begin{tabular}{|c|c|c|}
\hline Measure & $\begin{array}{l}\text { Married } \\
\text { early }\end{array}$ & $\begin{array}{l}\text { Married } \\
\text { late }\end{array}$ \\
\hline \multicolumn{3}{|l|}{ AGENCY } \\
\hline \multicolumn{3}{|l|}{ Autonomy in decision making } \\
\hline Choosing friends & 94.5 & 94.8 \\
\hline Purchasing clothes & 72.7 & $77.9^{* * *}$ \\
\hline Spending money & 77.4 & $80.9^{* * *}$ \\
\hline All three & 66.9 & $71.6^{* *}$ \\
\hline \multicolumn{3}{|l|}{ Self-efficacy } \\
\hline Able to express opinions to elders & 24.5 & $32.6^{* * *}$ \\
\hline $\begin{array}{l}\text { Able to confront person who said/ } \\
\text { did something wrong }\end{array}$ & 30.9 & $35.4^{* *}$ \\
\hline Able to do both & 16.0 & $22.9^{* * *}$ \\
\hline \multicolumn{3}{|l|}{ GENDER-ROLE ATTITUDES } \\
\hline $\begin{array}{l}\text { Believes wife beating is not justified } \\
\text { in any circumstances }\end{array}$ & 35.6 & $46.7^{* * *}$ \\
\hline \multicolumn{3}{|l|}{ REPRODUCTIVE HEALTH } \\
\hline $\begin{array}{l}\text { Used contraceptives to delay } \\
\text { first pregnancy }\end{array}$ & 3.4 & $11.2^{* * *}$ \\
\hline Had first delivery in health facility & 44.5 & $70.0^{* * *}$ \\
\hline Had miscarriage/stillbirth & 16.6 & $9.0 * * *$ \\
\hline
\end{tabular}




\begin{tabular}{|c|c|}
\hline Measure & Odds ratios \\
\hline \multicolumn{2}{|l|}{ MARRIAGE PLANNING†,‡ } \\
\hline \multicolumn{2}{|l|}{ MARITAL RELATIONSHIP§,††,㧊 } \\
\hline $\begin{array}{l}\text { Spousal communication on general matters } \\
\text { Spousal communication on }\end{array}$ & $1.05(0.90-1.22)$ \\
\hline reproductive matters & $0.89(0.77-1.04)$ \\
\hline Spousal interactions & $1.36(1.12-1.65)^{* *}$ \\
\hline Physical violence§§ & $0.63(0.53-0.74)^{* * *}$ \\
\hline Sexual violence§§ & $0.73(0.64-0.84)^{* * * *}$ \\
\hline \multicolumn{2}{|l|}{ 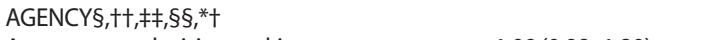 } \\
\hline Autonomous decision making & $1.09(0.98-1.20)$ \\
\hline Self-efficacy & $1.10(0.93-1.30)$ \\
\hline \multicolumn{2}{|l|}{ 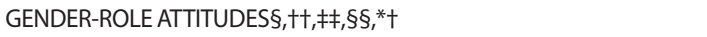 } \\
\hline Nonacceptance of wife-beating & $1.24(1.07-1.45)^{* *}$ \\
\hline \multicolumn{2}{|l|}{ REPRODUCTIVE HEALTH§,†† } \\
\hline Used contraceptives to delay first pregnancy§§ & $1.38(1.05-1.81)^{* *}$ \\
\hline Had first delivery in health facility§§ & $1.42(1.18-1.70)^{* * * *}$ \\
\hline Had miscarriage/stillbirth* $\neq$ & $0.55(0.45-0.66)^{* * *}$ \\
\hline \multicolumn{2}{|c|}{$\begin{array}{l}{ }^{* *} \mathrm{p} \leq .01 .{ }^{* * * *} \mathrm{p} \leq .001 .+ \text { Controls for work status before marriage. } \neq \text { Controls for } \\
\text { peer connectedness before marriage. } \S \text { Controls for work status in past year. } \\
++ \text { Controls for household wealth. } \neq \neq \text { Controls for spousal age difference. } \S \text { Con- } \\
\text { trols for spousal interaction. }{ }^{*}+\text { Controls for civic/social participation. }{ }^{*} \neq \text { Controls } \\
\text { for experience of physical violence. Notes: Odds ratios are from separate mul- } \\
\text { tivariate logistic regression analyses. All analyses control for years of schooling } \\
\text { and place and state of residence; other variables included as controls in each } \\
\text { analysis are indicated by footnotes. }\end{array}$} \\
\hline
\end{tabular}

nonegalitarian attitudes about wife-beating; only $36 \%$ of those who had married early and $47 \%$ of those who had married late believed that wife beating is not justified under any of the four specified circumstances.

\section{Reproductive Health}

Young women who had married before age 18 differed from those who had married later on all three sexual and reproductive outcomes. For example, the use of contraceptives to delay a first pregnancy was far less prevalent among those who had married early than among those who had married late (3\% vs. $11 \%$ ); the same was true for having had one's first delivery at a health facility ( $45 \%$ vs. $70 \%$ ). In addition, young women who had married early were more likely than others to have had a miscarriage or stillbirth (17\% vs. $9 \%$ ).

\section{Multivariate Analyses}

Most of the associations between age at marriage and the indicators discussed above remained significant after we adjusted for such characteristics as the young woman's educational level, work status, place of residence, household wealth, spousal age difference and state of residence (Table 4). For example, the odds that a woman had been involved in planning her marriage or reported all three types of spousal interaction were greater among those who had married at age 18 or older than among those who had married early (odds ratio, 1.4 for each). Conversely, women who had married late had reduced odds of having experi- enced physical violence (0.6) or sexual violence (0.7) within the marriage. Early marriage was not associated with measures of spousal communication.

No indicator of agency was related to marriage timing in the multivariate analyses. However, delayed marriage was positively associated with nonacceptance of wife-beating (odds ratio, 1.2).

All of the bivariate associations observed between marriage timing and the reproductive health indicators remained statistically significant in the multivariate analyses. Young women who had married late were more likely than those who had married early to have used a contraceptive method to delay their first pregnancy (odds ratio, 1.4) and to have had their first delivery in a health facility (1.4). They were less likely than others to have experienced pregnancy loss (0.6).

\section{DISCUSSION}

Our findings underscore that early marriage continues to be highly prevalent in India and is associated with a wide variety of marital and reproductive outcomes.

The finding that young women who had married early were less likely than others to have been involved in planning their marriage is consistent with observations from earlier studies in India. ${ }^{39}$ It may be related to the more traditional family backgrounds of women who marry early and to the difficulties these women encounter in asserting themselves when decisions are being made about such major issues as marriage.

While some studies have not found an association between women's age at marriage and their decision-making power, ${ }^{40,41}$ others suggest that early marriage tends to compromise women's autonomy. ${ }^{15}$ Our findings conform to the former view; when we controlled for factors known to influence women's autonomy, such as education, work, and spousal age differences and interactions, women who had married late were no more likely than those who had married early to have participated in making decisions pertaining to day-to-day matters or to have expressed self-efficacy.

However, our findings indicate that early-marrying women were more likely than other women to consider wife-beating justifiable, a finding also observed in other settings. ${ }^{14-19}$ This association may reflect that women who marry at young ages tend not only to have a traditional family background, but also to have gendered socialization experiences while growing up that continue to color their gender-role attitudes. They may also be less likely to have been exposed to modern ideas. ${ }^{32}$

In addition, timing of marriage was closely associated with the nature of a woman's marital relationship. We found that young women who had married early were less likely than those who had married late to have engaged in certain activities (e.g., going out to see a film) with their husband in recent months. These findings are consistent with a number of studies in India that have found that married adolescents are far less likely than women who had married when 18 or older to report having a close mar- 
ital relationship with their husband; $28,32,42$ they also corroborate observations from other settings ${ }^{43}$ that in societies where marriages between relative strangers are arranged at young ages and where marital living arrangements typically involve residing in extended families, the expression of affection between spouses often incurs disapproval that may work against the formation of intimate ties. Our findings, moreover, highlight that as in several other studies, ${ }^{14,16,44-46}$ women who marry early have an elevated risk of experiencing physical and sexual violence within marriage.

In addition, we found that women who had married early were less likely than others to have used contraceptives to delay a first pregnancy, corroborating findings from other studies in India. ${ }^{47}$ This association may reflect the strong pressures that most young Indian women face to prove their fertility soon after marriage, as well as the limited contact that adolescent and young couples typically have with the health care system prior to parenthood; 48,49 young women who marry early may be disproportionately affected by these constraints. That women who had married early were less likely than others to have had an institutional delivery for their first birth may be attributed partially to lack of knowledge of sexual and reproductive matters among young women who marry early and their families. ${ }^{26,32}$ Finally, our analyses suggest that young women who had married early were more likely than others to have experienced at least one pregnancy loss, a finding also observed in other settings. ${ }^{50}$ Further explorations are needed to see whether this association reflects an elevated risk of pregnancy-related complications among women who become pregnant at a young age or differences between early- and late-marrying women in the adoption of preventive care practices and the utilization of health care services during pregnancy.

This study had some limitations. Because of the crosssectional nature of the data, we cannot infer causal relationships between early marriage and the outcome indicators; however, the temporal ordering is consistent with early age at marriage having a causal influence on most indicators. Moreover, because our focus was to explore whether age at marriage is correlated with particular indicators, we considered only a few key background variables; other unmeasured factors may confound these associations.

Nevertheless, our findings provide a strong rationale for increasing the age at marriage among young women, and can be used in advocacy efforts to convey to stakeholders the importance of delaying girls' marriages. The study results-particularly the elevated levels of spousal interactions, the lower levels of violence and higher rates of desirable pregnancy-related outcomes associated with older age at marriage-may help build community support for delaying marriage among both youth themselves and their families. They may also encourage greater commitment on the part of government agencies to enforcing existing law on the minimum age at marriage, and encourage school, health and other authorities to support young women in negotiating with their parents to delay marriage.

The findings of this study may be particularly compelling for parents, who must also be made aware that early marriage may compromise young women's lives and their reproductive health and choices in multiple ways.

The reality that, despite current program efforts, early marriage will continue to characterize the lives of large proportions of young women in India, underscores the need for programs that support newly wed young women; such programs should acknowledge that these women's needs may differ from those of married adults. Efforts are needed to address the multiple vulnerabilities faced by young women who marry early-for example, by implementing programs that enable them to have greater control over resources, break down their social isolation and encourage couple communication, negotiation and conflict management skills early in marriage. Intervention models have attempted to address these needs in India, 5,51,52 and these approaches should be reviewed and expanded as appropriate so that married young women have the opportunity to exercise control over their lives.

Encouraging signs are evident. Policies and programs related to the Departments of Women and Child Development, the Ministry of Health and Family Welfare and the Department of Youth have recognized the importance of preventing early marriage and improving sexual and reproductive health and choice among young people. This study extends our understanding of the ways in which early marriage may compromise young women's lives and reproductive health and choices and can inform the content of relevant programs. What is needed now is to ensure that such programs reach young people and the influential adults in their lives, and that promising interventions are assimilated and scaled up.

\section{REFERENCES}

1. Ministry of Health and Family Welfare, National Population Policy 2000, New Delhi: Government of India, 2000.

2. Ministry of Youth Affairs and Sports, National Youth Policy 2003, New Delhi: Government of India, 2003.

3. Ministry of Women and Child Development, National Policy for the Empowerment of Women, New Delhi: Government of India, 2001.

4. Ministry of Law and Justice, Prohibition of Child Marriage Act, 2006, No. 6 of 2007, Jan. 10, 2007, Government of India.

5. Das Gupta S and Pande R, Knot Ready: Documenting Initiatives to Delay Early Marriage: Update 1, Washington, DC: International Center for Research on Women (ICRW), 2008.

6. International Institute for Population Sciences (IIPS) and Macro International, National Family Health Survey (NFHS-3), 2005-06: India, Vol. 1, Mumbai: IIPS, 2007.

7. Jain S and Kurz K, New Insights on Preventing Child Marriage: A Global Analysis of Factors and Programs, Washington, DC: ICRW, 2007.

8. Mathur S, Greene M and Malhotra A, Too Young to Wed: The Lives, Rights and Health of Young Married Girls, Washington, DC: ICRW, 2003.

9. Mensch BS, Singh S and Casterline JB, Trends in the timing of first marriage among men and women in the developing world, in: Lloyd $\mathrm{CB}$ et al., eds., The Changing Transitions to Adulthood in Developing Countries: Selected Studies, Washington, DC: National Academies Press, 2005, pp. 118-171. 
10. United Nations Children's Fund (UNICEF), Early Marriage: A Harmful Traditional Practice, New York: UNICEF, 2005.

11. International Centre for Diarrhoeal Disease Research, Bangladesh, Consequences of early marriage on female schooling in rural Bangladesh, Health and Science Bulletin, 2007, 5(4):13-18.

12. Lloyd CB and Mensch BS, Marriage and childbirth as factors in school exit: an analysis of DHS data from Sub-Saharan Africa, Policy Research Division Working Paper, New York: Population Council, 2006, No. 219 .

13. Mensch BS, Bruce J and Greene ME, The Uncharted Passage: Girls Adolescence in the Developing World, New York: Population Council, 1998.

14. ICRW, Development Initiative on Supporting Healthy Adolescents (DISHA) Project, Washington, DC: ICRW, 2005.

15. Jensen R and Thornton R, Early female marriage in the developing world, Gender and Development, 2003, 11(2):9-19.

16. Joshi A et al., Experiences and perceptions of marital sexual relationships among rural women in Gujarat, India, Asia-Pacific Population Journal, 2001, 16(2):177-194.

17. Khan ME, Townsend JW and D'Costa S, Behind closed doors: a qualitative study on sexual behaviour of married women in Bangladesh, Culture, Health and Sexuality, 2002, 4(2):237-256.

18. Ouattara M, Sen P and Thomson M, Forced marriage, forced sex: the perils of childhood for girls, Gender and Development, 1998, 6(3):27-33.

19. Puri M, Cleland J and Matthews Z, Extent of sexual coercion among young female migrant workers and their sexual health problems in Nepal, paper presented at the annual meeting of the Population Association of America, Minneapolis, MN, USA, May 1-3, 2003.

20. Miller S and Lester F, Improving the health and well-being of married young first-time mothers, paper presented at the Technical Consultation on Married Adolescents, Geneva, Dec. 9-12, 2003.

21. Lloyd C, ed., Growing Up Global: The Changing Transitions to Adulthood in Developing Countries, Washington, DC: National Academies Press, 2005

22. Santhya KG, Understanding Pregnancy-Related Morbidity and Mortality Among Young Women in Rajasthan, New Delhi: Population Council, 2009

23. UNICEF, The Progress of Nations 2001, New York: UNICEF, 2001.

24. Bruce J and Clark S, The Implications of Early Marriage for HIV/AIDS Policy, New York: Population Council, 2004.

25. Clark S, Early marriage and HIV risks in sub-Saharan Africa, Studies in Family Planning, 2004, 35(3):149-160.

26. Santhya KG and Jejeebhoy SJ, Early marriage and HIV/AIDS: risk factors among young women, Economic and Political Weekly, 2007, 42(14):1291-1297.

27. Alexander M et al., Formation of Partnerships Among Young Women and Men in Pune District, India, New Delhi: Population Council, 2006.

28. Barua A and Kurz K, Reproductive health-seeking by married adolescent girls in Maharashtra, India, Reproductive Health Matters, 2001 9(17):53-62

29. IIPS and ORC Macro, National Family Health Survey (NFHS-2), 1998-99, India, Mumbai: IIPS, 2000.

30. Ram F et al., Marriage and Motherhood: An Exploratory Study of the Social and Reproductive Health Status of Married Young Women in Gujarat and West Bengal, India, New Delhi: Population Council, 2006.

31. Ram U et al., How early marriage compromises girls' lives and reproductive health and choices in Maharashtra: evidence from the Youth in India, Situation and Needs Study, paper presented at the International Seminar on Changing Transitions to Marriage: Gender Implications for the Next Generation, New Delhi, Sept. 10-12, 2008.

32. Santhya KG and Jejeebhoy SJ, Sexual and reproductive health needs of married adolescent girls, Economic and Political Weekly, 2003, 37(41):4370-4380

33. Santhya KG, Jejeebhoy SJ and Ghosh S, Early Marriage and Sexual and Reproductive Health Risks: Experiences of Young Women and Men in Andhra Pradesh and Madhya Pradesh, India, New Delhi: Population Council, 2008.

34. Office of the Registrar General and Census Commissioner, Census of India 2000, age groups, 2001, <http://www.censusindia.gov.in/ Census_Data_2001/Census_Data_Online/Social_and_cultural/Age_ Groups.aspx>, accessed Nov. 27, 2008

35. Ministry of Statistics and Programme Implementation, Gross state domestic product at current prices, 2008, <www.mospi.nic.in/6 gsdp_cur_9394ser.htm>, accessed Mar. 27, 2008.

36. Office of the Registrar General and Census Commissioner, Census of India, Provisional Population Totals, Series I, Paper I of 2001, New Delhi: Office of the Registrar General and Census Commissioner, 2001.

37. Office of the Registrar General, SRS Based Abridged Life Tables 2001-2005, SRS Analytical Studies Report No. 3 of 2007, New Delhi: Office of the Registrar General, India, 2007.

38. IIPS and Population Council, Youth in India: Situation and Need 2006-2007, Mumbai: IIPS, 2010

39. Santhya KG, Haberland N and Singh AK, 'She Knew Only When the Garland Was Put Around Her Neck': Findings from an Exploratory Study on Early Marriage in Rajasthan, New Delhi: Population Council, 2006.

40. Balk D, Individual and community aspects of women's status and fertility in rural Bangladesh, Population Studies, 1994, 48(1):21-45.

41. Niraula BB and Morgan SP, Marriage formation, post-marital contact with natal kin and autonomy of women: evidence from two Nepali settings, Population Studies, 1996, 50(1):35-50.

42. Kulkarni S, The reproductive health status of married adolescents as assessed by NFHS-2, India, in: Bott $\mathrm{S}$ et al., eds., Towards Adulthood: Exploring the Sexual and Reproductive Health of Adolescents in South Asia, Geneva: World Health Organization, 2003, pp. 55-58.

43. Fricke $T$ and Teachman JD, Writing the names: marriage style, living arrangements, and first birth interval in a Nepali society, Demography, 1993, 30(2):175-188

44. Jejeebhoy SJ and Cook RJ, State accountability for wife-beating: the Indian challenge, Lancet, 1997, 349(Suppl. 1):SI10-SI12.

45. Jejeebhoy SJ and Bott S, Non-consensual sexual experiences of young people: a review of evidence from developing countries, South and East Asia Regional Working Paper, New Delhi: Population Council, 2003, No. 16

46. Khan ME et al., Sexual violence within marriage, Seminar, 1996, No. 447 , pp. $32-35$.

47. Raj A et al., Prevalence of child marriage and its effect on fertility and fertility-control outcomes of young women in India: a cross-sectional, observational study, Lancet, 2009, 373(9678):1883-1889.

48. Santhya KG and Jejeebhoy SJ, Young people's sexual and reproductive health in India: policies, programmes and realities, South and East Asia Regional Working Paper, New Delhi: Population Council, 2007, No. 19.

49. Santhya KG, Jejeebhoy SJ and Ghosh S, Addressing the Sexual and Reproductive Health Needs of Young People: Perspectives and Experiences of Stakeholders from the Health and Non-health Sectors, New Delhi: Population Council, 2007

50. Shawky $S$ and Milaat $\mathrm{W}$, Cumulative impact of early maternal marital age during the childbearing period, Paediatric and Perinatal Epidemiology, 2001, 15(1):27-33.

51. Daniel EE, Masilamani R and Rahman M, The effect of community based reproductive health communication interventions on con- 
traceptive use among young married couples in Bihar, India, International Family Planning Perspectives, 2008, 34(4):189-197.

52. Santhya KG et al., Empowering Married Young Women and Improving Their Sexual and Reproductive Health: Effects of the First-Time Parents Project, New Delhi: Population Council, 2008.

\section{RESUMEN}

Contexto: Hay muy poca evidencia disponible de India sobre las formas en que el matrimonio temprano puede poner en riesgo el futuro, la salud reproductiva y las opciones de maternidad de las mujeres jóvenes.

Métodos: Datos sobre 8,314 mujeres casadas en edades de 20-24 años de cinco estados indios, obtenidos a partir de un estudio representativo a nivel sub-nacional, se usaron para comparar los resultados maritales y reproductivos en mujeres jóvenes que se habian casado antes de los 18 años y en las que se casaron a una mayor edad. Se condujeron análisis de regresión logística para identificar asociaciones entre el momento del matrimonio y los resultados de interés.

Resultados: Comparadas con las mujeres que casaron antes de los 18, las jóvenes que se había casado a mayor edad tenían mayor probabilidad de haber participado en la planificación de su matrimonio (razón de momios, 1.4), de rechazar la violencia contra la mujer (1.2), de haber usado anticonceptivos para posponer su primer embarazo (1.4) y de haber tenido su primer parto en una institución de salud (1.4). Y tuvieron menor probabilidad de haber experimentado violencia física o sexual en su matrimonio (0.6-0.7), y de haber tenido un aborto espontáneo o muerte fetal (0.6), que las mujeres que se casaron a menor edad.

Conclusiones: Los hallazgos subrayan la necesidad de fortalecer el apoyo entre las jóvenes y sus familias para retrasar el matrimonio, y aplicar las leyes existentes relativas a la edad minima al casarse. También indican la importancia de alentar a las autoridades escolares, sanitarias y de otros sectores de que apoyen a las mujeres jóvenes en la negociación con sus padres para retrasar el matrimonio.

\section{RÉSUMÉ}

Contexte: Les données probantes sont rares, en Inde, concernant les effets préjudiciables du mariage précoce sur la vie et sur la santé et les choix génésiques des jeunes femmes.

Méthodes: Les données relatives à 8.314 femmes mariées de 20 à 24 ans vivant dans cinq états du pays, obtenues d'une étude sous-nationale des transitions vécues par les jeunes, servent à comparer les issues matrimoniales, génésiques et autres entre les jeunes femmes mariées avant l'âge de 18 ans et celles mariées plus tard. Les associations entre le moment du mariage et les issues considérées sont identifiées par analyses de régression logistique.

Résultats: Les jeunes fermmes mariées à l'âge de 18 ans ou audelà sont plus susceptibles que celles mariées avant l'âge de 18 ans d'avoir participé à la planification de leur mariage (rapport de probabilités, 1,4), de rejeter la violence conjugale (1,2), d'avoir pratiqué la contraception pour différer leur première grossesse $(1,4)$ et d'avoir accouché de leur premier enfant dans un établissement de santé $(1,4)$. Elles sont moins susceptibles que leurs homologues mariées à un âge précoce d'avoir subi de violences physiques $(0,6)$ ou sexuelles $(0,7)$ au sein de leur mariage ou d'avoir fait une fausse couche ou accouché d'un mortné $(0,6)$.

Conclusions: Les observations de l'étude soulignent la nécessité de renforcer parmi les jeunes et leurs familles la volonté de repousser l'âge du mariage. Elles mettent aussi en évidence le besoin de faire respecter les lois existantes sur l'âge minimum au moment du mariage et d'encourager les autorités scolaires, sanitaires et autres à soutenir les jeunes femmes dans leurs négociations avec leurs parents en faveur de mariages différés.

\section{Acknowledgments}

The authors gratefully acknowledge the support of the John D. and Catherine T. MacArthur Foundation and the David and Lucile Packard Foundation. We are grateful to Komal Saxena and M.A. Jose for their support and assistance in preparing the manuscript.

Author contact: kgsanthya@popcouncil.org 